\title{
YVES LÜGINBÜHL (ED.): NOUVELLES URBANITÉS, NOUVELLES RURALITÉS EN EUROPE
}

\author{
(Peter Lang, Bruxell, 2007, 532 o.)
}

\section{SCHUCHMANN JÚLIA}

Mi jellemző a mai városi és falusi térségek társadalmi és gazdasági fejlődésére? Mi jellemző a városi és a falusi térségek viszonyára az Európai Unió országaiban? Egyáltalán, beszélhetünk-e még a globalizálódó és metropolizálódó Európában hagyományos értelemben vett városról és falusi térröl? Hogyan definiálható a mai modern város? Adminisztratívan meghatározott településtípusként, vagy statisztikai jelenségként, meghatározott népességszámmal, a szolgáltatási funkciók széles körével, a gazdaság jellegével? A falusi térségek az alacsonyabb népsürúséggel, a szolgáltatási funkciók szűk körével, a mezőgazdaság dominanciájával? Igaz-e az a sokat hangoztatott tétel, miszerint a felgyorsuló urbanizáció, a kiterjedt és egyre terjeszkedő nagyvárosi agglomerációs övezetek a város egyértelmü győzelmét jelentik a falusi tér felett? Milyen válaszokat adnak a falusi terek a felgyorsuló urbanizációs folyamatok kihívásaira?

Ezekre az érdekfeszítő kérdésekre kereste és találta meg a választ az Yves Lüginbühl által szerkesztett, ,Nouvelles urbanités, nouvelles ruralités en Europe" címủ tanulmánykötet, amely 2007-ben Bruxellben, a Peter Lang kiadó gondozásában jelent meg. A könyv tanulmányainak alapját a 2000 májusában Strasbourgban az Európa Tanács épületében tartott (a könyv címével megegyezö elnevezésü) nemzetközi konferencián elhangzott elöadások anyaga adta. Az 532 oldalas könyvben 82 szerző 53 , tematikus rendbe szerkesztett tanulmányát olvashatjuk.

A könyv alkotói szerint Európában új típusú területi folyamatok indultak meg. A korábbi város-falu kettősség, ami a gazdasági és társadalmi fejlettségi dimenziók ellentmondásaiban jelent meg, már nem állja meg a helyét. Az európai városok és különösen a metropoliszok vonzáskörzetében fekvő falusi térségek társadalma és gazdasága átalakulóban van, mégpedig többek között az uniós közösségi politikák (a regionális, az agrár, a gazdaságpolitikák, a strukturális és a kohéziós politikák) erőteljes hatásai miatt is. A társadalmi-gazdasági átalakulás és fejlödés új irányai a könyv szerint jól kimutathatóan (és tudományosan mérhetöen) négy nagy területen jelentek meg:

1) egyrészt a lakásmód, lakóhely jellegének átalakulásában és fejlődésében,

2) másrészt a gazdasági átalakulásában, a munkavégzés új formáinak megjelenésében,

3) harmadrészt a demokratikus döntéshozás különböző területi szinteken való megvalósulásában, a helyi szinttől az európai szintig, 
4) és végül a társadalmak és a természeti környezet új viszonyában, a környezeti konfliktusok kezelésében.

A könyv a jelzett négy területnek megfelelóen négy tematikus fejezetre tagolódik. A fejezetek az adott témába illeszkedỏ elméleti és empirikus tanulmányokat tartalmaznak.

A tanulmánykötet terjedelmére való tekintettel nincs mód minden tanulmányt részletesen ismertetni, ezért most fejezetenként azt a négy tanulmányt emelnénk ki, amelyek a város és vidék újszerủ kapcsolatára, társadalmuk, térszerkezetük átalakulásának folyamatára adnak példákat. A könyv szerkesztője által írt problémafelvető és gondolatébresztô bevezetó után az elsö fejezet 16 tanulmánya a lakás- és életmód átalakulását vizsgálja meg és elemzi. A tanulmányok az európai nagyvárosok körüli szuburbán fejlödéssel foglalkoznak, mely kitủnően jelzi a város és vidék funkcionális kapcsolatrendszerének átalakulóban levő folyamatát. Érdekes esettanulmányokat olvashatunk a francia agrártérségek ủj típusú funkcióváltásáról, a vidék felértékelődéséről a városi polgárság körében, a vidéki háznak, mint második otthonnak a terjedéséről, a vidék társadalmi összetételének változásáról. A témában írt munkák közül kiemelnénk Martine Berger tanulmányát, amely a párizsi régióban vizsgálja a lakásmód és ezzel összefüggésben az életmód átalakulását. A tanulmányból kiderül, hogy a szuburbanizációs folyamatok terjedésével párhuzamosan növekedett a családi házas építkezési mód. Jelenleg a párizsi régióban a lakásállomány több mint fele családi ház. Kutatásai rámutatnak arra is, hogy a belváros és környéke közti társadalmi különbségek jelentős mértékben növekedtek. A legmagasabb társadalmi státuszúak a belvárosban laknak, míg a kevésbé tehetős társadalmi státuszúak a vidéki térségekben koncentrálódnak. (Ez más európai trendekkel is egybevág.) A szerzô fontos megállapítása, hogy a városi és a falusi társadalmak közti különbség ma már nem annyira a lakóhelytől függ, mind inkább a jövedelmi helyzet különbségeitől. A lakóhelyválasztást a munkahelyek és azok egyenlőtlen térbeli elhelyezkedése, valamint az ingatlanárak határozzák meg. Martine Berger kutatásai szerint a falusi térségekben romlottak a munkalehetőségek, miközben a városokban javultak. Ezért Párizs körül egyre kiterjedtebbé válik a fơváros ingázó övezete.

A könyv második nagy fejezete a gazdaság, a termelés és munkavégzés formáinak átalakulása szempontjából vizsgálja meg a folyamatokat. Számos esettanulmány a mezőgazdaság jövőjének kérdéskörével foglalkozik, az Unió közös agrárpolitikájának társadalmi-gazdasági hatásait tárja fel. A nyugat- és dél-európai országok közötti összehasonlítások eredményeként kiderülnek az új kihívásokra (a közös piac, a közös agrárpolitika, az új társadalmi elvárások, az élelmiszerbiztonság stb.) adott új, differenciált mezőgazdasági ,válaszok”. Vannak tanulmányok, amelyek az iparral foglakoznak, annak területi dinamikáját vizsgálják, fơként az európai városok leromlott ipari rozsdaövezeteinek megújulási lehetőségeit nézik, konkrét példákon keresztül. Az adott fejezetben különösen figyelemre méltó Y. Harffés H. Lamarche: A munkavégzés új formái a mezögazdaságban, hasonulás az iparral? címủ tanulmánya, amely a munkavégzés formáinak átalakulását vizsgálja a mezőgazdaságban, valamint az agrár és az ipari termelési módok közötti közeledés folyamatait. A tanulmány 
Tér és Társadalom 21. évf. 2007/4. 213-234. p.

szerint a francia mezőgazdaság 1960-as, 1970-es években kezdődő modernizációja eredményeképpen a tradicionális kisméretú családi gazdaságok és üzemek a megnövekedett gazdasági versenyben vagy lemaradtak és eltủntek, vagy bekapesolódtak egy új típusú, az ipari termeléshez hasonlítható, nagyüzemi mezỏgazdasági termelésbe. Ennek eredményeképpen az agrártársadalom is átalakult, átstrukturálódott. Emiatt már tarthatatlan a város és a falu szerepének hagyományos megítélése. A mezőgazdaság ugyanazon törvényszerüségeknek engedelmeskedik, mint a másik két nagy termelő ág, az ipar és a szolgáltató szektor, melyeket eddig a város privilégiumának tekintettünk.

A könyv harmadik nagy fejezetének tematikájába illeszkedő tanulmányok az Európai Unió regionális politikảjảnak a területi fejlödésre gyakorolt hatásait vizsgálják J.-J Helluin: Melyek ma Európában a területi politikák új eszközei a társadalmi szegregáció elleni küzdelemben? címú tanulmánya a mai európai társadalmigazdasági folyamatok erősen szegregált tereit mutatja be. A társadalmi szegregáció nem csupán a nagyvárosok belsỏ problémája, a szegregáció több térségi szinten, közte nagytérségi szinten, illetve a városi és a rurális régiók között is megjelenik. A szerző szerint a társadalmi szegregáció a mai európai társadalmi-gazdasági folyamatok „kedvezötlen mellékhatásaként” értelmezhetô. A probléma csak az érintett társadalmi csoportok bevonásával oldható meg.

A könyv negyedik, utolsó nagy fejezetének tanulmányai a város és falu problematika környezeti kérdéseivel és ellentmondásaival, elsősorban a társadalmi-gazdasági fejlödés környezeti hatásaival foglalkoznak. Kiemelnénk $C h$. $T$. Soulard: A természeti környezet, mint termelési eröforrás? gondolatébresztő címmel jegyzett íását. Az esettanulmány a francia Yonne megye példáját hozza, ahol a mezőgazdasági tevékenység következtében nitráttal szennyeződött az ivóvíz. A tanulmányból kiderülnek a gazdasági fejlődés (itt a mezőgazdasági termelés) negatív környezeti hatásai, valamint képet kapunk a környezeti problémák által különféleképpen érintett társadalmi szereplőkről, a köztük meglévő érdekellentétekröl, s ezek feloldási lehetőségeiröl is. A tanulmány arra is rávilágít, hogy miközben a gyorsan terjedő urbanizációs folyamatok kedvezőtlen környezeti hatásai egyre nyilvánvalóbbá válnak, a mai civil társadalom (a városi és a rurális egyaránt) egyre érzékenyebb a természeti környezeti problémákra, egyre nagyobb értékké válik a tiszta víz, a levegő, elótérbe kerül a természeti erőforrásokkal való fenntartható gazdálkodás fontossága. Ez a szemléletmód a mai európai társadalmak paradigmaváltását is jelzi, nevezetesen, hogy a falusi terek a mindennapi élet számára, de a városi középosztály számára is felértékelödtek, hiszen terjednek a vidéki nyaralók, a második otthonok, amit a rurális térségek funkcionális és gazdasági átalakulása alapozott meg. Ezek között is kiemelten a falusi turizmus, a biogazdálkodás terjedése. A fejezet egyben kitér a keletközép-európai országok környezeti problémáira is. Itt olvashatjuk Szirmai Viktória: Protection de l'environment dans le développment des territoires urbains en Hongrie tanulmányát, mely a környezetszennyezés okozta társadalmi konfliktusokat mutatja be a kilencvenes évek eleji Magyarországon. A tanulmány szerint a társadalmi környezeti konfliktusok felszinre kerülése fontos lépcsőfokok voltak a kelet-közép- 
európai országok modern polgári környezetvédelmi demokratikus intézményrendszerének kialakulásában és a civil társadalom megerösödésének folyamatában is.

A tanulmánykötetet Michael Rochefort, nemzetközileg ismert francia geográfus összegző tanulmánya, a téma továbbgondolását is segítỏ újabb tudományos kérdések zárják. A francia professzor szerint sem kétséges, hogy ma átalakulóban van a város és a falu, átalakulóban van a kapcsolatrendszerük is. Kialakulóban van egy új típusú európai térszerkezet, melyben a város és falu újradefiniálja önmagát. Ezért a tudománynak új meghatározásokat kell találnia a két településtípusra. Ma, ahogy az a tanulmányokból kiderült, nem tehető egyértelmủ különbség falu és város között az életmód vagy akár a foglalkozási szerkezet szerint. Michael Rochefort szerint a jövőben egyre több ember fog más településen dolgozni, mint ahol lakik. Megerősödhetnek a megapoliszok, a nagyvárosok körül egyre kiterjedtebb agglomerációs zónák lesznek. Ez új kutatási kérdéseket vet fel. Köztük például, hogy vajon a szuburbanizáció folyamata súlyosbítani fogja-e a térbeli társadalmi szegregációt vagy sem? Várható-e, hogy a periurbán térségek társadalmilag egyre homogénebbek és egyre szegregáltabbak lesznek? Várható-e Európában is a latin-amerikai modell, ahol a nagyvárosok körül a gazdag és a szegény elővárosok váltják egymást? De ezek a kérdések már egy másik könyv témái lehetnek.

Összességében egy nagyon jól felépített, rendkívül aktuális kérdésekkel foglalkozó, igényes megjelenésủ könyvet foghat kezébe az Olvasó. A könyv különlegessége és egyedisége abban rejlik, hogy a városi és a falusi tér fejlódését komplex folyamatként értelmezi, egyszerre próbálja megragadni annak társadalmi, gazdasági és környezeti oldalait. Fontos a tanulmányok szemléletmódja is, amennyiben a városi és a falusi társadalmak átalakulását az életmód általános átalakulásával is érzékeltetik. Ezt a könyvet ajánljuk mindazoknak, akik érdeklődnek a legfrissebb város és falukutatási eredmények iránt, akik szeretnének átfogó képet kapni a legújabb európai területi folyamatokról, a város-falu kapcsolatrendszerekről és az azokat meghatározó tényezőkről. 